\title{
Using Mobile Devices and Gaming as a Means of Building Vocabulary
}

\author{
http://dx.doi.org/ijim.v5i4.1683 \\ Dr. J. B. Redd, Dr. D. Schmidt \\ Iowa State University, Ames, IA, USA
}

\begin{abstract}
Mobile devices are gaining momentum and popularity in the daily lives of today's youth. These devices embrace and encourage ubiquitous learning through their ease of portability and access to various activities that can allow for learning to occur. Learning theories and cognitive techniques are explored as a means of providing a mobile educational experience that is individualized, motivational, and beneficial for transfer to later word learning and reading comprehension.
\end{abstract}

Index Terms-mobile devices, game theory, gaming in education, vocabulary

\section{INTRODUCTION}

"The digital world has placed the great library resources of the world at anyone's fingertips" --([46] p.v)

This article provides a review of the literary foundation for the basis of studying vocabulary acquisition using mobile devices. The main areas discussed include mobile devices, theoretical frameworks, game theory and design, games in education, and vocabulary learning techniques as they relate to vocabulary acquisition by high school students. Each of these areas plays an instrumental role in providing the background required to study the impact mobile technologies can have on vocabulary development.

\section{A. Mobile Devices}

Technology is constantly evolving and this change is moving into the educational realm by creating opportunities for enhanced learning that is characterized as mobile learning, seamless learning, and ubiquitous learning [78]. This learning can be accomplished through the use of mobile devices. Mobile devices are small portable computing devices that can be used in a variety of environments [61]. This includes handheld devices, such as, personal digital assistants (PDA), portable media players (iPod Touch), and handheld game consoles (Nintendo DS). They possess the features of an operating system, a processor unit, a microbrowser, input/output devices, memory, and batteries [40]. These devices are making their way from outside to inside classrooms. They provide a way for students to construct knowledge and meaning from experiences by accomplishing learning tasks by using a portable tool [78]. Many of these mobile devices are characterized as miniature classroom computers that allow students to partake in the "anytime, anywhere" learning movement [82]. Mobile devices may be useful in creating a way for secondary students to transfer learning from inside to outside the classroom seamlessly.

The use of mobile devices, such as the iPod Touch, is becoming more common among secondary students. For example, [1] found that $69 \%$ of iPod Touch users are be-

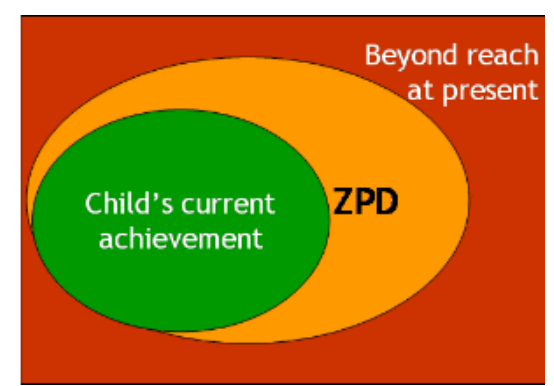

Figure 1. Three stages of the Zone of Proximal Development [5]

tween 13-24 years of age with $46 \%$ of the users between 13 and 17. Similarly, [52] found that $74 \%$ of teens (ages 12-17) own an iPod or Mp3 player. As mobile devices get more advanced, the possible educational applications improve, which can lead to a re-organization of the learning environment [39]. Reference [27] notes there are many ways to incorporate the use of mobile devices and library activities, such as searching for and reading information (i.e. Kindle App) or interacting with the environment (i.e. Google Goggles). Reference [21] describes a variety of ways of using mobile devices, for example, composing podcasts and movies. Mobile devices allow secondary students to engage in educational activities using the devices they are accustomed to.

\section{THEORETICAL FRAMEWORKS RELATED TO LEARNING WITH MOBILE DEVICES}

Behind the scenes of these mobile devices are theories at work that describe the way with which learning can occur. Three learning theories, Zone of Proximal Development, Social Learning Theory, and The Law of Effect, offer an explanation as to how learning can occur using this type of portable device.

\section{A. Zone of Proximal Development}

One-way knowledge is constructed via a mobile device is based upon Vygotsky's Theory of Zone of the Proximal Development. This theory highlights the space between the actual level of problem solving and the level that can be achieved through guidance and support [98] (see Fig. 1).

This theory can be broken down into three stages that look at what the learner can do alone, the level he wants to achieve, and the scaffolding and support necessary to achieve that level. The first stage is independent. This is the learner's present knowledge and skill level and where he feels comfortable and will have success achieving and solving problems on his own. The next stage is where the zone of proximal development rests. The learner through 
guidance and collaboration is able to work on something that is just above the level where he can complete it independently, but not so difficult it causes confusion or boredom [64]; [98]. The ultimate goal of providing these supports is to build up the learner's knowledgebase so he can later perform the tasks independently. The third stage is frustration. This is what happens when a learner attempts to move beyond his current knowledge level without the proper support. Mobile devices have the ability to engage players individually while in the zone of proximal development.

While using mobile devices, players move beyond their current skill level with the mobile device acting as a scaffold [8]; [28]. This theory suggests learners work within the state of instruction and development [15]. By using the mobile device with a vocabulary game, players are introduced via instruction to words that are currently beyond their knowledge base but within their grasp. Then through interaction with these words, provided by strategically placed scaffolds, knowledge of the vocabulary words is attained. Reference [8] describes, "Knowledge within a discipline is important, but solving problems that encourage students to go beyond their current skill and knowledge level is critical to effective instruction” (para. 20). This can apply to learning vocabulary words with a mobile device since the game is designed to provide support beginning with meeting the player at his present knowledge level. Then through these scaffolded experiences, knowledge levels advance beyond what they were before. Slowly, the scaffolds are phased out, leaving the learner with the ability to apply the knowledge gained with support into scenarios without any support [15]; [64]. Ultimately, it is the learner's goal to possess knowledge on the particular subject area independently, thus allowing for the cycle to once again begin.

Typically, games designed for mobile devices push players beyond their current knowledgebase slowly and with support. For example, the Playstation 3 game, Brain Challenge, starts at the level where the player is currently. Then through a self-adjusting difficulty system, the questions on topics, such as logic, math, and concentration adjust depending on the responses and choices made by the player [73]. The Zone of Proximal Development seeks to engage learners at the optimal instructional level in a safe and supported manner. Another theoretical model that explores the way learning occurs with a mobile device is based on social learning theory.

\section{B. Social Learning Theory}

The use of mobile devices also coincides with Bandura's Social Learning Theory. This theory notes that the actions of a person are strongly influenced by their consequences [6]. After discovering the effects of performing a behavior, the learner mentally begins to anticipate the possible consequences of the behavior [6]. Then matching behaviors are performed with the concept of reinforcement in mind. Learning in this manner takes into consideration four essential components. These include attention, retention, reproduction, and motivation [16]; [26]; [43]; [62].

These four essential components may be applied to learning with a mobile device. First, the amount of attention paid to the task and the steps needed to complete it are essential for success while playing games. For example, having knowledge that a certain behavior will reap certain rewards will cause extra attention to be paid to models and important components deemed necessary in order to achieve the reward [6]. Second, the images and text encountered on the device aid in remembering the content experienced. Memory is used to organize and mentally code the items, which were paid attention to and experienced [51]. Third, based on the feedback from the game the user's behavior is modified and reproduces the correct responses for success. This can also be considered imitative learning because by observing and focusing on the feedback provided, decisions are made that will attempt to maximize the rewards earned [6]. Finally, there are motivational incentives when it comes to games. This can be in the form of intrinsic factors, such as satisfactory feelings of learning something new by means of curiosity, exploration, and manipulation, or extrinsic factors, such as incentives, rewards and punishments, co-operation, and completion [16]. Another theoretical framework that can explain how learning transpires through trial and error while using a mobile device is based on Thorndike's theory of law of effect.

\section{Law of Effect}

The theory of law of effect is based on choosing the path of least resistance toward a goal that results in the greatest satisfaction [95]. The theory explains that behaviors are modified based upon experiences and their consequences [96]. This theory is best exemplified by trial and error learning [86]. The luxury of using a mobile gaming device is the repeated opportunities to engage in an activity. Then if the strategy used was not successful or did not, for example, earn the most points, the player has the ability to try it again and modify the original behaviors based upon the feedback received. Increasingly, the level of satisfyingness felt while completing the activity is the goal [96]. Reference [26] describes, "The learner is rewarded or punished depending upon what he does; the 'effect' (satisfaction or annoyance) contingent upon how the learner responds to the environment” (p. 15). The interaction allows for the learner to try out different actions and experience rewards and punishments based upon those decisions. These can cause an increase in the motivation and attention the learner may exhibit while playing a game [26]. Once the learner has discovered the behavior principle behind the learning, which can occur through a combination of positive and negative reinforcements, the learner can continue to learn in new contexts [12]; [26]; [87]. Playing a game on a mobile device can create new educational possibilities of learning.

The theoretical foundations for learning on a mobile device can be constructed through the combination of these three theories. The Zone of Proximal Development explains how these devices can bridge the gap of learning through well-constructed scaffolds. Social Learning Theory illustrates the impact that attention, motivation, and feedback can have on the player. Finally, theory of law of effect highlights the importance of trial and error learning opportunities and the effects of feedback in the games. Together, these three theories lay the foundation for learning on a mobile device. Also of importance is the programming that goes into the development of gaming applications. The construction of a game is based on the game theory, which includes the foundational elements, such as choices, rules, and goals, that are instrumental to the proper unfolding of a game [47]. 


\section{GAME THEORY}

Game theory defines the core structure of a game by developing and providing numerous sequences of decisions and choices pre-programmed into the gaming structure that will allow the player to progress based upon their own actions. This theory develops gaming sequences based upon utility, or the probability that a selection will be made by the player [81]. Reference [13] describes the following:

Within game theory, the structural elements of a game exist as rules, turns, collaboration and competition, where winning, or fun, is modeled as numerical payoff. Game theory explains how playing (a game) works, and defines games as an interactive process striving toward payoff. (p. 7)

This theory is based on decisions. As decisions are made, they should be well-informed and based on prior knowledge learned through experiences in the game [47]. Inside of a game there are decision trees that create various paths based on the choices made by the player [74]; [81]. Each decision causes a chain reaction leading to a different outcome.

As the player progresses, his interactions within the game help to evolve into strategies that maximize the chance of success at reaching predetermined goals [10]; [11]; [20]. For example, the Leapster Explorer Learning Game, Mr. Pencil Saves Doodleburg, introduces the player on how to write numbers and letters and to create art and recognize shapes [50]. Reproducing the correct symbols allows Mr. Pencil to progress though the game and save the town. There are rules built into the game that funnel the player's actions to have specific consequences. This means there are multiple paths to success solely dependent on the actions and decisions of the player. For example, if the letters are not correctly traced, the player has to start again, and when correctly traced, the player proceeds to more difficult activities.

Game theory explains how the achievement principle applies to learning with games. Reference [31] notes learners while gaming are impacted by the intrinsic rewards. The rewards are customized based on the player's movements. As the levels shift, the effort and skill mastery required by the player also does [38]. The rewards signify the growing achievements earned by the player. Every player's experience is different with the same game [20]. A common algorithm implemented into the design of a game is based on the SuperMemo Method. This method offers a custom, adaptive spaced repetition program adapted to suit the learner's abilities [92]. Information is strategically placed in increments that complement the curve most commonly associated with forgetting (see Fig. 2).

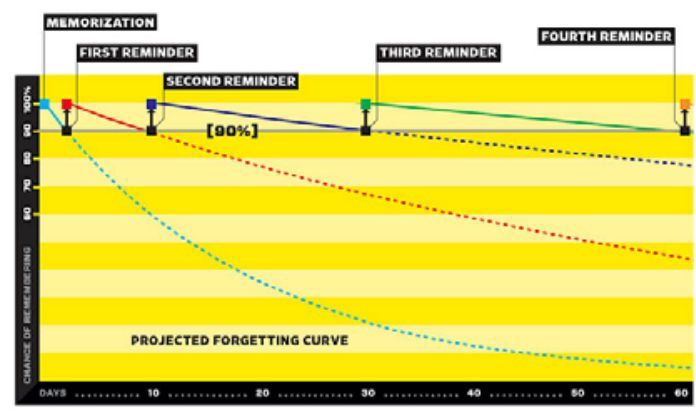

Figure 2. Game algorithm that replicates the forgetting curve [103]
The game begins at the player's knowledge level and then moves through playful, free movements within a well-defined, rigid structure at a level and pace that best suits the player [13]. Reminders are spaced after the first introduction of material in order to reduce forgetting. This is accomplished through practice and easily refined through active integration, meaningful use, and repetition [88]. Reference [31] concludes that a virtual world provides the player with numerous opportunities for practice that is not boring since it allows for the player to create their own experiences. Through these interactions with the games by means of images, text, and actions, players' skills and knowledge are then constructed. The design and development involved in the creation of the game creates an environment conducive for learning.

\section{GAME DESIGN}

The design of a game can take on two formats [56]. The most common is a linear format. This is where the player, after making a certain response, receives a reinforcement or reward, and then progresses onto the next frame. The second format involves branching. This is when the next page to be encountered varies upon the action performed by the player. A branching game is well designed when no two students follow the exact same pathway through the learning experience [46]. Based on this format, the player has multiple ways to make progress in the game by making choices based on individual strengths and learning styles [31].

There is an overarching, basic design, though, that games must follow. Reference [54] notes that games should possess three essential characteristics. The first, challenge, means that games will shift in complexity based upon the user's actions. There is a goal to be reached and when play begins, the user is uncertain of the outcome. The second, fantasy, creates mental images. These images allow the learner to relate prior knowledge toward the understanding of new items [54]. Fantasy involves evoking the senses through the use of images, plot structure, and sound effects. The third essential characteristic is curiosity. By having a game that possesses the "optimal level of informational complexity," the users are engaged and not overwhelmed [54], p. 42.

Games also need to adjust to the player's skill level, offer elements of surprise, and appeal to emotions [33]; [57]; [89]. The design of a game begins with a clear goal structure that offers scoring and feedback along the way [14]; [57]. The feedback mechanism offers valuable information to the player, which will shape his later decisions and actions within the game [30]. The feedback helps a player progress by offering corrective information and emotional support [93]. Reference [35] notes games allow learning to change by providing opportunities to fail safely and create memory knowledge that can improve later recall and performance.

The knowledge built into memory is a key component of learning and the design of a game needs to take this into account. Memory involves the activities of acquiring, retaining, and recalling information [16]. The act of learning involves taking new information presented and intertwining it with previous knowledge in a meaningful way [25]; [41]. Then, the act of analyzing, synthesizing, and developing critical thinking skills evolves as the player moves through the game and takes the information previously encountered and remembered and builds upon it 
[24]. Reference [26] found the following, "Learning is a continuous process of combining the familiar with the new.” (p. 114). The amount and extended opportunities of practice are instrumental components of the design of a game to aid in memory and the learning process. The use of gaming in education can allow for these types of opportunities to occur.

\section{GAMING IN EDUCATION}

Historically, video games were only seen as a form of entertainment, but as the technologies progress, these tools are becoming increasingly more popular as new mediums for education [85]. Reference [45] defines a game as "purposeful, goal-oriented, rule-based activity that the players perceive as fun” (p. 14). Mattel released the first handheld game, Football, in 1977 [45]. This first game was primitive in the design and artificial intelligence as the range of actions allowed in the game was quite limited. Over the years, this type of game has advanced in complexity and design so that it is now used on cell phones and other portable devices. For example, some games today have motion sensors and touch screens that react based on the player's movements (i.e., Wii, iPods). Mobile devices have increased in processor power and screen resolution and allow for gamers to play for a few minutes here and there since they are always connected [45].

As the evolution of mobile devices dramatically increases every year, so do the possible applications within the educational realm. Technology in and of itself can create activities that allow students to master and experience things that could not be discovered in another manner. Reference [89] discusses the possibilities of educators using video games as a model to improve learning environments by providing clear goals, challenging students, allowing for collaboration, using criterion-based assessments, giving students more control over the learning process, and incorporating novelty into the environment. In regard to video games as a means of learning, [59] concludes digital games allow for the unfolding of actions and interactions to happen naturally, slowly revealing the path to success as opposed to traditional games, which state the rules up front. Reference [59] goes on to explain that digital gaming environments need to support the varying pace of the learners. This is necessary to build up the player's gaming confidence by encouraging and motivating them with the drive to continue to play and succeed. Also, using games allows learners to experience things that would be difficult to replicate in another manner. For example, the game, Go, Diego, Go: Safari Rescue for the Wii, allows the player to go on an African safari rescue with the game's characters. Together, they save the animals from the mischief of a magician while at the same time collecting stamps and photos of the different locations visited [68]. Another game, Sid Meir's Civilization Revolution for the Nintendo DS, allows players to construct an entire empire from the very beginning. This includes activities such as waging war, conducting diplomacy, and discovering new technologies [69]. Games give players the opportunity to experience things that otherwise would not be possible.

Gaming provides a method of instruction in education that may allow for greater learning outcomes. Reference [70] implemented a computer memory concepts activity with 88 high school students. Approximately, half of the students experienced the activities by means of a game and the others used non-gaming techniques. Based upon a computer memory knowledge pre-test and post-test, the gaming students found the approach more effective and motivational in the memorization of concepts. Reference [97] studied the effect that a 3D geography game they developed had on 24 upper elementary students. They reported significant learning gains made by students while participating in the game (based on pre- and postachievement tests) and a dramatic increase in motivation to engage in the game-based learning environment.

Understanding the possibilities that gaming can provide in education is vital to the success of this method of teaching. Reference [77] concludes when preservice teachers are instructed on possible uses of digital games in education, the view of how these games might be effective shifts dramatically in favor of the game's potential positive impact on learning. Games that connect educational needs and games elements (visualization and problem solving) can lead to the most engagement by learners [4]. They also need to take into account the content, which encourages and promotes the learning of new material.

A video game's content is of great importance. [3] note that learning through video games is dependent upon the situation that it simulates as opposed to the characteristics of the computer itself. This means that it is not the hardware but rather the software. It is through the design and development of the features of the game that can promote learning opportunities [3]. The mobile device may be the technological tool, but it is material that comprises the game that harvests the potential learning possibilities. Reference [44] states the combination of digital games and quality learning content engages the learner during the process of learning. Then it is the interactions in this gaming medium that allows for the mastery of material in a personalized manner.

Using a mobile gaming device allows the player to master the skills of the game while learning about the content of the game itself. Reference [91] states that game playing requires the ability to read and interpret the rapidly changing images encountered. While in the gaming environment, the player needs to comprehend and analyze the various amounts of information he encounters. This helps to refine reading skills. Also, developing an understanding of the rules of the game is an important component of playing the game [9]. Reference [71] found that by making sure students understand what is expected of them, students often do better. It is not just understanding the game's rules, but it also requires active participation in comprehending and internalizing what is required of them. The active engagement with the game creates the opportunity for learning to occur.

\section{A. Gaming and Active Learning}

Using games in education provides teachers with ways that allow students to become active participants in their educational experience. Reference [29] describes games as "action-and-goal-directed preparations for, and simulations of, embodied experience” (p. 201). Games provide the medium for learning, but in order to gain the full experience submersed in a gaming environment, the player needs to become an active participant-a producer-playing toward the completion of goals/win state [29]. Games can enhance learning by providing an active method of building knowledge that was not previously possible [101]. The 
use of a game on a mobile device creates new and possibly even more powerful methods of educating a generation of students that have grown up accustomed to using the technology accessible to them.

Games give the player a chance to participate in a series of activities from a particular perspective toward the accomplishment of a goal in the manner they see fit [29]; [93]. While using games, players are actively working toward the completion of a series of tasks toward a goal. Reference [60] defines, "Active learning refers to techniques where students do more than simply listen to a lecture. Students are DOING something including discovering, processing, and applying information” (para. 1). This means students are in charge of their learning; they are involved and engaged [100]. Reference [49] found that only $30 \%$ of students in college level physics courses of a traditional nature had a grasp on fundamental acceleration concepts whereas with active learning activities using computer software and other tools, this percentage increased to $75 \%$. The use of games as a form of active learning can also be exemplified by the game, River City. This game encourages small group collaboration to determine the cause of illness in the $19^{\text {th }}$ century. Based on realistic historical, sociological, and geographical data, together the group members actively look for solutions to the outbreak by formulating hypotheses, conducting experiments, and recommending possible solutions [94]. Gaming allows users to participate in the construction of their own knowledge by connecting concepts and applications. Reference [48] remarks games encourage active learning, collaboration, and interactivity. Games allow for collaboration, practice, discussion and negotiation within a virtual environment. Through hands-on manipulation of this virtual environment, students are actively shaping their knowledge and learning at the same time.

The idea of active learning through game usage creates an environment where the learner is in charge of his actions: learning by doing [23]; [91]. The game provides the format for the learning and by its basic design "all aspects of the learning environment are set up to encourage active and critical, not passive learning” [31]. p. 49. Reference [17] found that computer-based video game playing improved fact differentiation/recall processes as well as problem-solving skills by allowing for the exploration of multiple problem solutions. Part of the learning that evolves when using a gaming technology is the aspect of problem solving in addition to learning the basic facts.

Active learning using a mobile device allows each individual student to have a different experience with the game. Reference [58] notes video games allow the players to navigate different scenarios facing the consequences of varying actions. By making decisions the learner is in control of what happens next. The mobile device provides the means for an individualized educational experience that allows the learner to take on a more active role where learning does not occur by just listening but rather by doing [80]. Through active engagement, students experience the curricular concepts "metal representations of coherent classes of entities", being taught by completing activities that require doing and then reflecting upon them [63], p. 11. These experiences have the capabilities to be transferred to new learning situations.

\section{B. Gaming and Transfer}

The use of gaming in education can create possibilities of transfer from one situation to another. Reference [48] concludes, "Creating opportunities for students to practice applying the material, such as in a game or simulation, can bridge the distance between learning concepts presented in a classroom and using the information to solve a problem met outside of the school" (p. 54). It is this transfer of knowledge that can have such a profound impact. When participating in these games, students gain a skill set that will help them work with others and apply the conceptual knowledge to new situations [48]. As the player progresses in a game, the concepts behind the game play are mastered as well as the content. By understanding the principles, procedures, and general rules behind the game, students can recognize the meanings of specific and factual events, which can lead to transferring these ideas into new settings [26]; [34]. A helpful component to transferring ideas and skills is the motivation that the game provides.

\section{Gaming and Motivation}

Games are a way to extend motivational factors that typically apply to their recreational use to that which can apply in the classroom. Using games in educational environments allow students to be taught in innovative ways that can increase their motivation while teaching content. Reference [58] concluded that games could address the systemic deficiencies that are present in today's traditional teaching formats. She notes that $86 \%$ of students who leave the engineering major cite poor teaching, predominantly lecture format, by faculty of undergraduate science and engineering classes as an influential factor. By transforming the way we teach, learning itself is transformed. Reference [58] reported that lectures had the lowest rated learning outcomes in today's classrooms, and using games increases the motivation of the students. For example, in the collegiate classroom, the games Geography Explorer and Virtual Cell increased students' learning outcomes by $15 \%-40 \%$ and $30 \%-63 \%$ respectively when compared to the lecture format. She concluded that video games provide one means of motivating students to learn. Reference [44] notes education needs to move away from the traditional lecture format toward one that emphasizes teamwork, independence, and responsibility. They found the use of mobile devices and a digital economy game as a learning mode led to an increase in positive student emotions and knowledge transfer as opposed to the traditional lecture method and the use of economy case studies. Gaming is a technology the students of this generation are accustomed to and instead of ignoring or avoiding it, needs to become implemented into the curriculum and pedagogy of educators [99]. Using teaching techniques that appeal to and motivate learners in class is key in today's classrooms.

Creating something that will appeal to and motivate the learners in today's classrooms is one of the possibilities available by using video games. Reference [83] discovered while adding interactive multimedia into his teaching repertoire to help promote active learning, students were more motivated to engage in class activities in an authentic and spontaneous manner. Reference [57] conducted a survey of computer game preferences and found that not one single game can appeal to everyone, but some factors that contribute to intrinsically motivating instruction in- 
clude personally meaningful goals, performance feedback, uncertain outcomes, scorekeeping, and randomness. In regards to increasing motivation, [57] concludes that personalization must be present. This involves a gaming environment that responds to the learners' actions as well as provide ample opportunity for reflecting upon their actions. A game can become personally motivating by allowing the player to create an account and each time he enters, he receives a personal message. He can also pull up his individual achievements previously attained on the game, for example, scores. Also, every gaming experience is different since the outcomes are based on the individual's actions. Games have the capabilities to move at the individual's pace and at their skill level, which can be an instrumental learning tool when mastering certain curricular concepts, such as vocabulary.

\section{Vocabulary DEVELOPMENT RELATED to GAMING}

Mastery of new vocabulary is a complex process, involving acquiring the words of a language [71]. The development of vocabulary is a major curricular concept addressed throughout the K-12 school curriculum. Academic vocabulary consists of content-specific, schooltask, and literary words [36]. A strong vocabulary has been linked as a catalyst for improving reading fluency [34]; [84]; [88]. In order to strengthen vocabulary, certain techniques might be implemented. This involves immersion in rich environments that provide rich and varied language experiences [32]; [76]; [102]. Reference [7] found that students immersed in a vocabulary-rich environment, who were provided with word instruction and learning strategies, ended up developing larger, more expansive vocabularies. The use of a computer game can mimic an immersive environment that permits the player to have multiple interactions with vocabulary words. An immersive environment allows for active inquiry and exploration in a defined space [18]; [79].

Immersive experiences in the gaming realm might be helpful for building a foundation for learning vocabulary. A word-rich environment is a catalyst for an increase in vocabulary usage and reading fluency [88]. Reference [53] notes, "Children learn language from their language experiences - there is no other way" (p. 168). The players, by taking on an active role by playing the game, master the game's components as well as the vocabulary based content of the game itself. Through interactions with different word activities, situations are created where learners can move at their own pace to master new vocabulary.

Reference [12] notes that games and word play provide a context where students can enjoy the process of learning. By playing games, various types of interactivity and engagement occur, such as player positioning, narrative, and choice [24]. Reference [67] reported the use of games contributed to the learning of vocabulary as long as the game allowed the student the opportunity to interact with the word through practice and review in an atmosphere optimal for learning (pleasant). The choice of the game should reflect the needs of the students, such as, proficiency level, cultural contest, and timing [68]. Engagement is important in learning scenarios in order to permit the learners to extract meaning and make sense of the information [22]; [48]; [75]. Reference [104] found that when engineering undergraduate students were given one of two conditions to learn English vocabularyexperimental (web sites with games) or control (face-to- face activity-based lessons)-those in the group using games statistically outperformed the control group. Also, many students found that the gaming format provided a context that made remembering of the vocabulary words easier.

\section{A. Word Activities}

Another key element that increases vocabulary learning is teaching individual words by providing concise and student friendly definitions [32]; [72]; [76]. Reference [55] found that when high school students were presented with concise vocabulary information through Short Message Service (SMS) messages as opposed to detailed print materials, more vocabulary was recognized on the posttest. The use of easily understandable definitions also has an impact. In a high school science classroom, [105] concluded that the use of definitions linked to related ideas and concepts ultimately lead to a better understanding of the words, which in turn impacted the overall understanding of the concepts they helped define. It is a combination of concise and understandable definitions that may contribute to the retention and learning of new vocabulary words.

Reference [32] notes it is important to engage students in a variety of word activities. This involves designing activities that take into account the multiple facets of a word and its meaning and how the word relates to other words. Reference [65] found that high school students involved in varied exposure to vocabulary words in meaningful contexts outperformed their peers on a vocabulary post-test. It is important that within vocabulary building activities the word is not learned as a stand-alone item, but rather to learn its connections with other words [90]; [105]. Within the gaming environment, this can be done by implementing various activities, such as, finding a word's synonyms and antonyms. Reference [37] found a significant difference in post-test scores between a group of elementary students who received vocabulary instruction with only electronic book activities (animations about six different vocabulary words) and those who received the electronic book along with feedback, prompting, and supplemental information. They concluded that it was important to use supplemental tools (e.g., synonyms and asking questions), not just books for engaging students in a variety of word learning formats.

Another important component to building a larger vocabulary involves repeated encounters with words. Reference [32] explains students should work with a word more than once. Building up a strong vocabulary is not something that can happen in just one day through one encounter. It needs to occur over a long period of time, incrementally, within more than one context [32]; [71]; [76]. This repeated exposure will help build word precision, which means developing an understanding of when it would be appropriate to use the word [72]. By interacting with a word multiple times via multiple activities, learning of words and the relationships between them occurs. Reference [106] concluded that L2 (English as a Second Language) students who received periods of reading and interactive vocabulary instruction showed an increase in vocabulary knowledge. This finding may provide an understanding regarding the way words and vocabulary are mastered. By understanding the skills needed to learn vocabulary, word development has the possibility to transfer into other scenarios. Reference [71] defines transfer as a 
movement beyond the texts to which the original learning is tied. This can be done by teaching word learning strategies within a contextual environment, such as a game [32]. Reference [66] explains the instruction of vocabulary should emphasize skill development and strategy building to allow for the growth of independent word learning. It is essential to not just teach words in isolation, but instead to teach the concepts and skills behind learning and mastering new words with the ultimate goal of transitioning the new words into one's vocabulary. By introducing functional and skill-based strategies for word learning in the English classroom, transfer applications emerge for application in other content areas within secondary classrooms [34].

\section{B. Vocabulary Acquisition}

New words are learned in a variety of ways in the secondary school context, for example, through reading literature [7]; [84]; [102]. A main staple of most high school literacy curriculum involves vocabulary acquisition [19]; [42]. Understanding and maintaining a strong vocabulary is essential for comprehending texts [34]. Unfortunately, with estimates at 88,500 word families known by ninth grade, there is no way they could all be covered by one teacher, which is where supplementary out-of-class activities come in [66]. Reference [66] claims that due to the large number of words encountered in reading, the approach to teaching vocabulary must include methods that increase the capabilities for children in secondary schools to learn vocabulary on their own. Vocabulary instruction should use a variety of approaches, methods, and techniques [2].

\section{CONCLUSION}

Through the implementation of a mobile learning device and a gaming tool, learning meets the needs of today's students of the learn anywhere and anytime movement. Vygotsky's Zone of Proximal Development, Bandura's Social Learning Theory, and Thorndike's Theory of Law of Effect, provide the theoretical base explaining how learning expands outside the restriction of the classroom building and one teacher's instructions by means of a mobile device. Students become actively in control of their own learning potential. The goal and intention of using this mobile device and game is to build up a student's word consciousness, which is "an awareness of and interest in words and their meanings" [7], p. 116. The use of word activities based on the secondary school curriculum and the way memory unfolds creates a supportive environment conducive for learning.

The design of the game holds great importance. It provides the structural element that houses the content material of vocabulary building. The design needs to take into account active learning essentials, game theory, future transfer implications as well as motivational principles. All of these elements together can encourage and contribute to the success of a player in the game.

\section{REFERENCES}

[1] Admob. (2009). New research on the demographics and behavioral characteristics of iPhone and iPod touch users. Retrieved on April 11, 2010, from http://blog.admob.com/2009/06/16/newresearch-on-the-demographics-and-behavioral-characteristics-ofiphone-and-ipod-touch-users-from-admob-and-comscore/

[2] Allen, J. (1999). Words, words, words: teaching vocabulary in grades 4-12. York, Maine: Stenhouse Publishers.
[3] Antonietti, A, \& Mellone, R. (2003). The difference between playing games with and without the computer: A preliminary view. The Journal of Psychology, 137(2), 133-144. http://dx.doi.org/10.1080/ 00223980309600604

[4] Amory, A., Naicker, K., Vincent, J., and Adams, C. (1999). The use of computer games as an educational tool: Identification of appropriate game types and game elements. British Journal of Education, 30(4), 311-321. http://dx.doi.org/10.1111/1467-8535.00121

[5] Atherton, J. S. (2010). Learning and Teaching; Constructivism in learning. Retrieved on September 26, 2010, from http://www.learningandteaching.info/learning/constructivism.htm

[6] Bandura, A. (2006). Analysis of modeling processes. In A. Bandura (Ed.), Psychological modeling: Conflicting theories, (pp.1-62). New Brunswick, New Jersey: Transaction Publishers.

[7] Baumann, J. F., Ware, D., \& Edwards, E. C. (2007). "Bumping into spicy, tasty words that catch your tongue": A formative experiment on vocabulary instruction. The Reading Teacher, 61(2), 108-122. doi: 10.1598/RT.61.2.1 http://dx.doi.org/10.1598/RT.61.2.1

[8] Benson, A. (1995). Review and analysis of Vygotsky's thought and language. Retrieved on July 11, 2008, from http://web.archive.org/web/20010414083709/http://129.7.160.115/INS T5931/Vygotsky.html

[9] Berger, A. A. (2002). Video games: A popular culture phenomenon. New Brunswick: Transaction Publishers.

[10] Birdwell, K. (2006). The cabal: Valve's design process for creating half-life. In K. Salen \& E. Zimmerman (Eds.), The game design reader, (pp. 212-225). Cambridge, Massachusetts: The MIT Press.

[11] Bjork, S., \& Holopainen, J. (2006). Game and design patterns. In K. Salen \& E. Zimmerman (Eds.), The game design reader, (pp. 410437). Cambridge, Massachusetts: The MIT Press.

[12] Blachowicz, C. L. Z., \& Fisher, P. (2008). Attentional vocabulary instruction: read-alouds, word play, and other motivating strategies for fostering informal word learning. In A. E. Farstrup \& S. J. Samuels (Eds.), What research has to say about vocabulary instruction (pp.3255). Newark, DE: International Reading Association.

[13] Botturi, L., \& Loh C. S. (2008). Once upon a game: Rediscovering the roots of games in education. In C. T. Miller (Ed.), Games: Purpose and potential in education, (pp.1-22). New York: Springer.

[14] Bowman, R. F. (1982). A "Pac-Man" theory of motivation: Tactile implications for classroom instruction. Educational Technology, 22(9), 14-17.

[15] Chaiklin, S. (2003). The zone of proximal development in Vygotsky's analysis of learning and instruction. In A. Kozulin, B. Gindis, V. S. Ageyev, \& S. M. Miller (Eds.), Vygotsky's educational theory in cultural context. (pp. 39-64). New York: Cambridge University Press.

[16] Child, D. (1993). Psychology and the teacher. $5^{\text {th }}$ ed. New York: Cassell.

[17] Chuang, T.-Y. \& Chen, W.-F. (2009). Effect of computer-based video games on children: An experimental study. Educational Technology, 12(2), 1-10.

[18] Colella, V. (2000). Participatory simulations: Building collaborative understanding through immersive dynamic modeling. The Journal of the Learning Sciences, 9(4), 471-500. http://dx.doi.org/10.1207/ S15327809JLS0904_4

[19] Common Core State Standards. (2010).English language arts standards: Language , grade 9-10, retrieved on October 31, 2010, from http://www.corestandards.org/the-standards/english-language-artsstandards/language/grade-9-10/

[20] Crawford, C. (1984). The art of computer game design. Berkley, CA: Osborne/McGraw-Hill.

[21] Croy, K. (2007). An iPod Touch in Every Classroom: Even More Innovative Techniques for Using iPods to Reach Students. Retrieved on October 21, 2010, form http://web.mac.com/kcroy/iPod/iPodcast/iPodcast.html

[22] Dede, C. (2000). Emerging influences of informational technology on school curriculum. Journal of Curriculum Studies, 32(2), 281-303. http://dx.doi.org/10.1080/002202700182763

[23] Devine, D. J., Habig, J. K., Martin, K. E., Bott, J. P., \& Grayson, A. L. (2004). Tinsel Town: A top management simulation involving distributed expertise. Simulation and Gaming, 35(1), 94-134. http://dx.doi.org/10.1177/1046878103258193 
[24] Dickey, M. D. (2005). Engaging by design: How engagement strategies in popular computer and video games can inform instructional design. ETR\&D, 53(2), 67-83. http://dx.doi.org/10.1007/BF02504866

[25] Donovan, M. S., Bransford, J. D., \& Pellegrino, J. W. (1999). How people learn: Bridging research and practice. Washington, D. C.: National Academies Press.

[26] Erickson, S. C. (1974). Motivation for learning: A guide for the teacher of the young adult. Ann Arbor: The University of Michigan Press.

[27] Fox, M. (2010). Mobile trends: Finding information on the web. Retrieved on October 30, 2010, from http://web.simmons.edu/ fox/ pda/fox_cil_2010.pdf

[28] Ganske, K. (2000). Word journeys: Assessment-guided phonics, spelling, and vocabulary instruction. New York: The Guilford Press.

[29] Gee, J. (2008). Learning theory, video games, and popular culture. In K. Drotner \& S. Livingstone (Eds.), The international handbook of children, media, and culture, (pp.196-211). Sage: Los Angeles.

[30] Gee, J. P. (2008). Video games, learning, and “content”. In C. T. Miller (Ed.), Games: Purpose and potential in education, (pp.43-53). New York: Springer.

[31] Gee, J. P. (2003). What video games have to teach us about learning and literacy. New York: Palgrave Macmillan.

[32] Graves, M. F. (2008). Instruction on individual words: One size does not fit all. In A. E. Farstrup \& S. J. Samuels (Eds.), What research has to say about vocabulary instruction (pp.56-79). Newark: DE: International Reading Association.

[33] Grodal, T. (2003). Stories for eye, ear, and muscles: Video games, media, and embodied experiences. In M. J. P. Wolf \& B. Perron (Eds.), Video game theory reader (pp. 129-155). New York: Routledge.

[34] Harmon, J. M., Wood, K. D., \& Hedrick, W. B. (2008). In A. E. Farstrup \& S. J. Samuels (Eds.), What research has to say about vocabulary instruction (pp.150-181). Newark: DE: International Reading Association.

[35] Harris, P. D. (2009, January). Immersive learning seeks a foothold. $T+D, 40-45$.

[36] Heibert, E. H. \& Lubliner, S. (2008). The nature, learning, and instruction of general academic vocabulary. In A. E. Farstrup \& S. J. Samuels (Eds.), What research has to say about vocabulary instruction (pp.106129). Newark: DE: International Reading Association.

[37] Higgins, N., \& Hess, L. (1999). Electronic books to promote vocabulary development. Journal of Research on Computing in Education, 31(4), 425. Retrieved from Academic Search Elite database.

[38] Holland, W., Jenkins, H., \& Squire, K. (2003). Theory by design. In M. J. P. Wolf \& B. Perron (Eds.), The video game theory reader, (pp. 25-46). New York: Routledge.

[39] Holzinger, A., Nischelwitzer, A., \& Meisenberger, M. (2005, November). Lifelong-learning support by m-learning: example scenarios. eLearn, 11. http://doi.acm.org/10.1145/1125280.1125284

[40] Hu, W., Yeh, J., Chu, H., \& Lee, C., (2005, September). Internetenabled mobile handheld devices for mobile commerce, Contemporary Management Research, 1(1), 13-34.

[41] Hunter, M. (1995). Retention theory for teachers. Thousand Oaks, CA: Corwin Press.

[42] Iowa Department of Education. (n.d.). Reading - grades 9-12. Retrieved on May 16, 2010, from http://www.corecurriculum.iowa.gov/ Discipline.aspx?C=Literacy\&D=Reading

[43] Kirsh, S. J. (2010). Media and youth: a developmental perspective. Malden, MA: Wiley-Blackwell.

[44] Kittl, C., Edegger, F., \& Petrovic, O. (2009). Learning by pervasive gaming: An empirical study. In Designing learning activities with mobile technologies. Innovative mobile learning H. Ryu \& D. Parsons (Eds.). Information Science Reference: Hershey.(pp. 60-82).

[45] Klopfer, E. (2008). Augmented learning: Research and design of mobile educational games. The MIT Press: Cambridge, Massachusetts.

[46] Kolb, L. (2008). Toys to tools: Connecting student cell phones to education. Eugene, Oregon: International Society for Technology in Education.

[47] Kremers, R. (2009). Level design: Concept, theory, \& practice. Natick, MA: A K Peters, Ltd.

[48] Kumar, R. \& Lightner, R. (2007). Games as an interactive classroom technique: perceptions of corporate trainers, college instructors and students. International Journal of Teaching and Learning in Higher Education, 19(1), 53-63.

[49] Laws, P., Sokoloff, D., \& Thornton, R. (1999). Promoting active learning using the results of physics education research. Retrieved on September 25, 2010, from http://sydney.edu.au/science/uniserve_science/ newsletter/vol13/sokoloff.html

[50] Leapfrog Enterprises. (2010). Leapster explorer learning game: $\mathrm{Mr}$ Pencil saves doodleburg. Retrieved on September 26, 2010, from http://shop.leapfrog.com/leapfrog/jump/Leapster-Explorer\%22Learning-Game\%3A-Mr.-Pencil-Saves-Doodleburg/productDetail/ Leapster-Explorer-Games/LEAPSTEREXPLORER39046/categoryId

[51] Learning Theories Knowledgebase. (2010, September). Social Learning Theory (Bandura) at Learning-Theories.com. Retrieved September 26th, 2010 from http://www.learning-theories.com/social-learningtheory-bandura.html

[52] Lenhart, A. (2009). Teens, mobile, \& games: An overview of Pew Internet data. Retrieved on December 1, 2010, from http://www.pewinternet.org/Presentations/2009/28--Teens-MobilePhones-and-Video-Gaming.aspx

[53] Lieven, E. \& Tomasello, M. (2008). Children's first language acquisition from a usage-based perspective. In P. Robinson \& N. C. Ellis (Eds.), Handbook of cognitive linguistics and second language acquisition (pp.168-196). New York: Routledge.

[54] Loftus, G. R., \& Loftus, E. F. (1983). Mind at play. New York: Basic Books, Inc.

[55] Lu, M. (2008). Effectiveness of vocabulary learning via mobile phone. Journal of Computer Assisted Learning, 24, 515-525. http://dx.doi.org/10.1111/j.1365-2729.2008.00289.x

[56] Lumsden, D. B. (1975). Adult learning and the applications of modern educational technology. In D. B. Lumsden \& R. H. Sherron (Eds.), Experimental studies in adult learning and memory (pp.97-114). New York: John Wiley \& Sons.

[57] Malone, T. W. (1984). Toward a theory of intrinsically motivating instruction. In D. F. Walker \& R. D. Hess (Eds.), Instructional software: Principles and perspectives for design and use (pp.68-94). Belmont, CA: Wadsworth. (Original work published 1981).

[58] Mayo, M. J. (2007, July). Games for science and engineering education. Communications of the ACM, 50(7), 31-35. http://dx.doi.org/10.1145/1272516.1272536

[59] McFarlane, A. (2007). Learning and lessons from the world of games and play. In R. Andrews \& C. Haythornthwaite (Eds.), The sage handbook of e-learning research (pp.119-137). London: Sage Publications.

[60] McKinney, K. (2010). Active learning. Retrieved on April 11, 2010, from http://www.cat.ilstu.edu/additional/tips/newActive.php

[61] Microsoft Corporation. (2010). 1.1 Glossary. Retrieved on October 16, 2010, from http://msdn.microsoft.com/en-us/library/ee394786(PROT. 13).aspx

[62] Moore, A. (1999). Albert Bandura. Retrieved on May 9, 2010, from http://fates.cns.muskingum.edu/ psych/psycweb/history/bandura.htm

[63] Murphy, G. L. (1991). Meaning and concepts. In P.J. Schwanenflugel (Ed.), The psychology of word meanings (pp.11-35). Hillsdale, New Jersey: Lawrence Erlbaum Associates.

[64] Murray, T. \&, Arroyo, I. (2002). Toward measuring and maintaining the Zone of Proximal Development in adaptive instructional systems. Retrieved on August 14, 2010, from http://centerforknowledgecommunication.info/publications/pubs6/ZPD OperationalITS.pdf

[65] Myers, J., \& Shu-fen, C. (2009). A multiple-strategy-based approach to word and collocation acquisition. IRAL: International Review of Applied Linguistics in Language Teaching, 47(2), 179-207. http://dx.doi.org/10.1515/iral.2009.008

[66] Nagy, W. E., \& Anderson, R. C. (1984). How many words are there in printed school English? Reading Research Quarterly, 19(3), 304-330. http://dx.doi.org/10.2307/747823

[67] Nguyen, T., \& Khuat, T. (2003). Learning vocabulary through games: The effectiveness of learning vocabulary through games. Asian EFL Journal, 5(4). Retrieved October 31, 2010, from http://www.asian-efljournal.com/dec_03_sub.Vn.php

[68] Nintendo. (2010). Go, Diego, go: Safari rescue. Retreived on September 25, 2010, from http://www.nintendo.com/games/detail/cPvFl9ofA xxVCaxnsZLIDBo4UO-xxcdC 
[69] Nintendo. (2010). Sid Meir's Civilization Revolution for the Nintendo DS. Retrieved on Sepetember 25, 2010, from http://www.nintendo. com/games/detail/6Y91Fl-sMWbs45VcU4cLwy7aIkz77JNx

[70] Papastergiou, M. (2009, January). Digital game-based learning in high school computer science education: Impact on educational effectiveness and student motivation. Computers \& Education, 52(1), 1-12. http://dx.doi.org/10.1016/j.compedu.2008.06.004

[71] Pearson, P. D., Hiebert, E. H., \& Kamil, M. L. (2007, April/June). Theory and research into practice: Vocabulary assessment what we know and what we need to learn. International Reading Association, 42(2), 282-296.

[72] Phythian-Sence, C. \& Wagner, R. K. (2007). Vocabulary Acquisition: A primer. In R. K. Wagner, A. E. Muse, \& K. R. Tannenbaum (Eds.), Vocabulary acquisition: Implications for reading comprehension, (pp.1-14). New York: Guilford Press.

[73] Play.com (2010). Playstation 3: Brain Challenge. Retrieved on September 26, 2010, from http://www.play.com/Games/PlayStation3/4/7856705/Brain-Challenge/Product.html?add=7856705\&source=9593 \& \$ ja=tsid:11853\%7Cprd:78888

[74] Poundstone, W. (2006). Game theory. In K. Salen \& E. Zimmerman (Eds.), The game design reader, (pp. 382-408). Cambridge, MA: The MIT Press.

[75] Prensky, M. (2005, September/October). Enrage me or engage me: What today's learners demand, EDUCAUSE, 60-64.

[76] Pressley, M., Disney, L., \& Anderson, K. (2007). Landmark vocabulary instructional research and the vocabulary instructional research that makes sense now. In R. K. Wagner, A. E. Muse, \& K. R. Tannenbaum (Eds.), Vocabulary acquisition: Implications for reading comprehension, (pp.205-232). New York: Guilford Press.

[77] Ray, B., \& Coulter, G. A. (2010). Perceptions of the Value of Digital Mini-Games: Implications for Middle School Classrooms, Journal of Digital Learning in teacher Education, 26(3), 92-100.

[78] Rogers, Y. (2009). How mobile technologies are changing the way children learn. In A. Druin (Ed.). Mobile Technology for Children: Designing for interaction and learning, (pp.3-22). Amsterdam: Morgan Kaufmann Publishers. http://dx.doi.org/10.1016/B978-0-12374900-0.00001-6

[79] Roussos, M., Johnson, A., Moher, T., Leigh, J., Vasilakis, C., Barnes, C., (1999). Learning and building together in an immersive virtual world. Retrieved on October 17, 2010, from http://www.evl.uic.edu/tile/NICE/NICE/PAPERS/PRESENCE/presenc e.html

[80] Ryu, H., \& Parsons, D. (2009). Designing learning activities with mobile technologies. In H. Ryu \& D. Parsons (Eds.), Innovative mobile learning, (pp.1-20). Information Science Reference: Hershey.

[81] Salen, K., \& Zimmerman, E. (2004). Rules of play: game design fundamentals. Cambridge, MA: The MIT Press.

[82] Schachter, R. (2009, Nov/Dec). Mobile devices in the classroom. District Administration, 31-36.

[83] Schrand, T. (2008, Spring). Tapping into active learning and multiple intelligences with interactive multimedia. College Teaching, 78-84. http://dx.doi.org/10.3200/CTCH.56.2.78-84

[84] Segalowitz, N., Watson, V \& Segalowitz, S. (1995). Vocabulary skill: Since-case assessment of automaticity of word recognition in a timed lexical decision task. Second Language Research, 11(2), 121-136. http://dx.doi.org/10.1177/026765839501100204

[85] Shreve, J. (2005). Let the games begin: Entertainment meets education. Retrieved on September 25, 2010, from http://www.edutopia.org/let-games-begin

[86] Simpson, E., \& Stansberry, S. (2008). Video games and teacher development: Bridging the gap in the classroom. In C. T. Miller (Ed.), Games: Purpose and potential in education, (pp.163-184). New York: Springer.

[87] Skinner, B. F. (2006). The science of learning and the art of teaching. In B. A. Marlowe \& A. S. Canestrari (Eds.), Educational psychology in context: Readings for future teachers (pp.45-55). Thousand Oaks, CA: Sage.
[88] Smith, T. B. (2008). Teaching vocabulary expeditiously: Three keys to improving vocabulary instruction. English Journal, 97(4), 20-25.

[89] Squire, K. (2003). Video games in education. International Journal of Intelligent Simulations and Gaming, 2(1).

[90] St. Clair Otten, A. (2003, July). Defning moment: teaching vocabulary to unmotivated students. The English Journal, 92(6), 75-78. http://dx.doi.org/10.2307/3650539

[91] Suoranta, J., \& Lehtimaki, H. (2004). Children in the information society. New York: Peter Lang Publishing.

[92] SuperMemo World. (2010). SuperMemo method. Retrieved on September 27, 2010, from http://www.supermemo.eu/supermemo method

[93] Sweetser, P., \& Wyeth, P. (2005, July). GameFlow: A model for evaluating player enjoyment in games. ACM Computers in Entertainment, 3(3), 1-24.

[94] The River City Research Team. (2007). Introducing River City. Retrieved on September 25, 2010, from http://muve.gse.harvard.edu/ rivercityproject/

[95] Thorndike, E. L. (1905). The elements of psychology. New York: A. G. Seiler. http://dx.doi.org/10.1037/10881-000

[96] Thorndike, E. L. (1913). Educational Psychology: The original nature of man. New York: Teachers College, Columbia University.

[97] Tuzan, H., Yilmaz-Soylu, M., Inal, Y., and Kizilkaya, G. (2009, January). The effects of computer games on primary school students' achievement and motivation in geography learning. Computers \& Education, 52(1), 68-77. http://dx.doi.org/10.1016/j.compedu.2008. $\underline{06.008}$

[98] Vygotsky, L. (1978). Mind in society: development of higher psychological processes. Cambridge: Harvard University Press.

[99] Weibe, G. (2007). Having fun is a good thing: Video games in education. Retrieved on October, 15, 2010, from http://www.slideshare.net/glennw98/having-fun-is-a-good-thing

[100]Wellert, P. (2008). Breaking the technology barrier: Using technology in education. Retrieved on June 17, 2009 from http://www.articlesbase.com/k-12-education-articles/breakingthetechnology-barrier-using-technology-in-education-581892.html

[101]Wideman, H. H., Owston, R. D., Brown, C., Kushnirul, A., Ho, F., \& Pitts, K. C. (2007, March). Unpacking the potential of educational gaming: A new tool for gaming research. Simulation \& Gaming, 38(10), 10-30. http://dx.doi.org/10.1177/1046878106297650

[102]Withrow, F. B. (2004). Literacy in the digital age: Reading, writing, viewing, and computing. Lanham, Maryland: ScarecrowEducation.

[103]Wolf, G. (2008). Want to remember everything you'll ever learn? Surrender to this algorithm read more. Retrieved on September 27, 2010, from http://www.wired.com/medtech/health/magazine/1605/ff_wozniak?currentPage=all

[104]Yip, F. W. M., \& Kwan, A. C. M. (2006). Online vocabulary games as a tool for teaching and learning English vocabulary. Educational Media International, 43(3), 233-249. http://dx.doi.org/10.1080/09523 $\underline{980600641445}$

[105] Young, E. (2005). The language of science, the language of students: Bridging the Gap with Engaged Learning Vocabulary Strategies. Science Activities, 42(2), 12-17. Retrieved from Academic Search Elite database. http://dx.doi.org/10.3200/SATS.42.2.12-17

[106]Zimmerman, C. B. (1997, Spring). Do reading and interactive vocabulary instruction make a difference? An empirical study. TESOL Quarterly, 31(1), 121-140. http://dx.doi.org/10.2307/3587978

\section{AUTHORS}

Dr. J. B. Redd is with Iowa State University, Ames, Iowa, 50011 (e-mail: jredd@iastate.edu)

Dr. D. Schmidt is with Iowa State University, Ames, Iowa, 50011 (e-mail: dschmidt@iastate.edu)

Received 28 May 2011. Published as resubmitted by the author 27 September 2011. 